\title{
ASPECTOS GERAIS DO XERODERMA PIGMENTOSO: UMA REVISÃo
}

\section{ARTIGO DE REVISÃO}

MOREIRA, Danilo José Silva ${ }^{1}$

FONSECA, Juliana Brito da ${ }^{2}$

ROSSI, Karoline ${ }^{3}$

VASCONCELOS, Suzana dos Santos ${ }^{4}$

OLIVEIRA, Vinicius Faustino Lima de ${ }^{5}$

DIAS, Claudio Alberto Gellis de Mattos ${ }^{6}$

OLIVEIRA, Euzébio de ${ }^{7}$

DENDASCK, Carla Viana ${ }^{8}$

${ }^{1}$ Acadêmico de Medicina. Universidade Federal do Amapá (UNIFAP).

${ }^{2}$ Acadêmica de Medicina. Universidade Federal do Amapá (UNIFAP).

${ }^{3}$ Acadêmica de Medicina. Universidade Federal do Amapá (UNIFAP).

${ }^{4}$ Acadêmica de Medicina. Universidade Federal do Amapá (UNIFAP).

${ }^{5}$ Acadêmico de Medicina. Universidade Federal do Amapá (UNIFAP).

${ }^{6}$ Biólogo, Doutor em Teoria e Pesquisa do Comportamento, Professor e pesquisador do Curso de Licenciatura em Química do Instituto de Ensino Básico, Técnico e Tecnológico do Amapá (IFAP).

7 Biólogo, Doutor em Doenças Topicais, Professor e pesquisador do Curso de Educação Física, Universidade Federal do Pará (UFPA).

8 Teóloga, Doutora em Psicanálise, pesquisadora do Centro de Pesquisa e Estudos Avançados (CEPA). 
ARAÚJJO, Maria Helena Mendonça de ${ }^{9}$

BRITO, Maysa Vasconcelos ${ }^{10}$

FECURY, Amanda Alves ${ }^{11}$

MOREIRA, Danilo José Silva. Et al. Aspectos gerais do xeroderma pigmentoso: Uma revisão. Revista Científica Multidisciplinar Núcleo do Conhecimento. Ano 05, Ed. 03, Vol. 11, pp. 114-126. Março de 2020. ISSN: 2448-0959, Link de acesso: https://www.nucleodoconhecimento.com.br/saude/aspectos-gerais-doxeroderma

\section{RESUMO}

O Xeroderma Pigmentoso (XP) é uma doença genética rara, de caráter recessivo e autossômico, que afeta igualmente os dois sexos e todas as etnias, estando associado intimamente a comunidades com alta taxa de consanguinidade. $O$ objetivo desta revisão foi detalhar as principais vias de reparo do DNA do XP, os diferentes defeitos funcionais que resultam no desenvolvimento dos 8 tipos de $\mathrm{XP}$, as principais características do quadro clínico de um paciente com $\mathrm{XP}$, as principais comorbidades associadas ao $\mathrm{XP}$, e os tratamentos disponíveis ou que ainda estão em estudos para indivíduos acometidos pelo XP. A pesquisa bibliográfica foi realizada nas bases de dados: Redalyc, Repositório institucional da Universidade Federal de Juiz de Fora, Scielo, Biblioteca Digital Brasileira de Teses e Dissertações, Science Research.com, Lilacs e Pub Med, utilizando palavras-chave ou suas associações: Xeroderma Xeroderma Pigmentoso. XP é uma doença genética que não tem cura; o indivíduo

${ }^{9}$ Médica, Mestra em Ensino e Ciências da Saúde, Professora e pesquisadora do Curso de Medicina do Campus Macapá, Universidade Federal do Amapá (UNIFAP). ${ }^{10}$ Biomédica, Doutora em Doenças Topicais, Professora e pesquisadora Faculdade Estácio de Sá, Macapá.

${ }^{11}$ Biomédica, Doutora em Doenças Topicais, Professora e pesquisadora do Curso de Medicina do Campus Macapá, Universidade Federal do Amapá (UNIFAP). 
com XP possui uma pele fotossensível e, quando exposto a radiação UV, pode desenvolver diversas complicações dermatológicas; as manifestações do XP estão diretamente ligadas ao defeito genético; a NER é sem dúvida a principal via de reparo do DNA quando se trata de XP; no XP-V o by-pass da fita com a lesão do DNA não é feito pela polimerase pol eta e sim por outra polimerase da família $Y$; os defeitos nas vias de reparo do DNA podem causar não somente o XP, mas também outras doenças; e o tratamento para o XP é paliativo. Consiste no uso de protetores UV específicos, fármacos, enzimas de reparo e vetores adenovirais, além de criocirurgia, terapia fotodinâmica (TFD), remoção cirúrgica de tumores e acompanhamento psicológico.

Palavras-chave: Xeroderma Pigmentoso, reparo, comorbidade, tratamento.

\section{INTRODUÇÃO}

O Xeroderma Pigmentoso (XP) é uma doença genética rara, de caráter recessivo e autossômico, que afeta igualmente os dois sexos e todas as etnias, estando associado intimamente a comunidades com alta taxa de consanguinidade (DANTAS, 2018; OLIVEIRA, 2003).

Sabe-se que há uma relação entre o desenvolvimento de XP e defeitos em vias de reparo do DNA, que consistem em mecanismos empregados pela célula para corrigir danos causados ao DNA, evitando a indução de mutações (SANTIAGO, 2015).

O desenvolvimento de cada um dos oito tipos de XP é condicionado por diferentes defeitos funcionais, que envolvem vias de reparo do DNA (SANTIAGO, 2015).

Indivíduos com XP, assim como em qualquer outra doença, apresentam características sintomatológicas que levam ao estabelecimento de um quadro clínico, que corresponde ao conjunto de sintomas apresentados pelo paciente (PRIBERAM DICIONÁRIO, 2020). 
Na literatura, encontram-se evidências da associação entre o XP e o desenvolvimento de outras comorbidades, que consistem na ocorrência de duas ou mais doenças ao mesmo tempo em um indivíduo (GOLDMAN; AUSIELLO, 2011).

Com o passar do tempo, para melhorar a qualidade de vida de um indivíduo com XP, foram desenvolvidos diversos tratamentos, que consistem em maneiras de cuidar de um paciente (SCOTTINI, 2017).

\section{OBJETIVOS}

Detalhar as principais vias de reparo do DNA do XP.

Detalhar os diferentes defeitos funcionais que resultam no desenvolvimento dos 8 tipos de XP.

Detalhar principais características do quadro clínico de um indivíduo com XP.

Detalhar as principais comorbidades associadas ao XP

Detalhar tratamentos disponíveis ou que ainda estão em estudos para indivíduos acometidos pelo XP.

\section{MÉTODO}

A pesquisa bibliográfica foi realizada nas bases de dados: Redalyc, Repositório institucional da Universidade Federal de Juiz de Fora, Scielo, Biblioteca Digital Brasileira de Teses e Dissertações, Science Research.com, Lilacs e Pub Med, utilizando palavras-chave ou suas associações: Xeroderma - Xeroderma Pigmentoso.

Os critérios de inclusão usados na realização das buscas foram a disponibilidade integral online, a abordagem direta sobre o XP ou sobre algum aspecto relevante em relação a esta patologia e texto do trabalho redigido na língua inglesa, portuguesa ou espanhola. Em relação aos critérios de exclusão aplicados, tem-se trabalhos duplicados e trabalhos realizados antes do ano 2000. 
Realizou-se uma pesquisa nas bases de dados mencionadas a fim de listar os trabalhos relacionados ao XP existentes na literatura. A partir de uma leitura prévia dos títulos e resumos dos trabalhos encontrados, descartou-se produções que não atendiam ao que era esperado para compor esta revisão. Realizou-se então a leitura do texto completo das produções que passaram pelas etapas anteriores, selecionando para esta revisão aquelas que abordavam aspectos relevantes do XP.

\section{RESULTADOS}

\section{VIAS DE REPARO DO DNA E XP}

A forma variante do XP (XP-V) está ligada a ausência da polimerase pol eta presente na via de reparo translesão (TLS) (CASTRO, 2016). Todas os demais tipos de manifestações do XP estão ligados diretamente a defeitos na via de Reparo por Excisão de Nucleotídeos (NER), a qual é formada pela ação conjunta de cerca de 30 proteínas (SANTIAGO, 2015).

A NER reconhece distorções espaciais na estrutura da molécula de DNA, corrigindo lesões causadas pela ação da luz ultravioleta (UV), produtos oriundos da ativação de hidrocarbonetos aromáticos policíclicos, produtos de origem oxidativa e produtos formados por quimioterápicos (MORI, 2015; MOURA, 2015; SANTIAGO, 2015).

NER possui duas vias: o Reparo Acoplado a Transcrição (TCR, do inglês Transcription Coupled Repair) e o Reparo Global do Genoma (GGR, do inglês Genome Global Repair) (MORI, 2015; MOURA, 2015; SANTIAGO, 2015).

TLS faz um by-pass de uma lesão espacial do DNA e a principal polimerase envolvida nesse processo é a pol eta. Na ausência de pol eta, a polimerase que faz o by-pass da lesão é a pol iota, que possui uma taxa de erro muito maior que pol eta (CASTRO, 2016; LERNER, 2014). 


\section{MECANISMOS GENÉTICOS ENVOLVIDOS COM O DESENVOLVIMENTO DO XP}

As sete proteínas do grupo de complementação Xeroderma Pigmentoso - XPA, XPB, XPC, XPD, XPE e XPF e XPG - integram a via NER do DNA. Complicações nos genes que codificam essas proteínas resultam em XP por ineficiência do NER (MORENO, 2017; SANTIAGO, 2015).

No XP-V, o funcionamento da via NER do DNA está normal, porém, a função da polimerase $\mathrm{pol} \eta$, enzima sintetizada a partir o gene POLH e responsável pelo by-pass do DNA, está comprometida, causando ineficiência da via TLS (MORENO, 2017).

\section{QUADRO CLÍNICO DO XP}

Paciente com XP pode apresentar manifestações clínicas de largo espectro: sensibilidade a radiação UV, predisposição para o desenvolvimento de tumores, envelhecimento precoce da pele, eritemas, complicações neurológicas e desenvolvimento corporal prejudicado (CHAIBUB, 2011; DANTAS, 2018; LEITE, 2008; VIANA, 2011).

\section{COMORBIDADES ASSOCIADAS AO XP}

A Síndrome de Cockayne, a Tricotiodistrofia e a Síndrome XP/deSanctis-Cacchione são doenças que possuem associação com o XP devido a existência de defeitos que impossibilitam que as vias de reparo do DNA funcionem perfeitamente. Esta síndrome incluir também perda auditiva neurossensorial, catarata, retinopatia pigmentar, fotossensibilidade cutânea e cárie dentária. (CASTRO, 2016; SOLTYS, 2010).

$\mathrm{Na}$ Tricotiodistrofia o indivíduo acometido pode apresentar baixa estatura, microcefalia, déficit cognitivo, fácie característica - queixo recuado e orelhas grandes -, displasia das unhas, fotossensibilidade, ictioses, inf ertilidade e maior predisposição a doenças infecciosas, (CASTRO, 2016; SOLTYS, 2010). 
A Síndrome XP/deSanctis-Cacchione consiste em um quadro de XP associado à coexistência de hipogonadismo, nanismo e doença neurológica severa no indivíduo acometido (LERNER, 2014; SOLTYS, 2010).

\section{TRATAMENTOS DISPONÍVEIS}

Basicamente, o tratamento gira em torno de remoção de eventuais tumores que surgirem e mudanças nos hábitos de vida do indivíduo acometido, tais como o uso de roupas longas e o exercício de atividades no período noturno (LERNER, 2014).

Isotretinoína (ácido cis-retinóico) é usada em alguns casos; outra ferramenta de tratamento é o uso de vetores adenovirais (LEITE, 2008). A criocirurgia ou crioterapia também é uma ferramenta alternativa para o tratamento de pacientes XP (ANTUNES; ANTUNES; SILVA, 2007). O uso TFD também é uma ferramenta que possibilita o tratamento dos canceres oriundos do XP (ZAMARRÓN et al., 2017).

\section{DISCUSSÃO}

\section{A VIA DE REPARO POR EXCISÃO DE NUCLEOTÍDEOS}

Quanto às etapas de NER, ocorre primeiramente a identificação da lesão, seguida pela abertura da dupla fita e a verificação da lesão. Logo após, é formado o complexo pré-incisional que acarreta o corte do oligopeptideo contendo a lesão e a síntese de reparo (MORI, 2015).

As duas sub vias da NER - TCR e GGR -, são classificadas conforme a maquinaria celular usada para efetuar o reparo (SANTIAGO, 2015).

Basicamente, a TCR-NER ocorre quando há um bloqueio à progressão da RNA polimerase I ou II (RNA pol). A proteína CSB (Cockayne Syndrome Complementation group $B$ ) possui uma alta afinidade pela RNA pol e acredita-se que essa interação aumenta de intensidade quando a RNA pol encontra alguns obstáculos físicos que a impedem a continuidade do processo de transcrição, resultando em uma interação 
intensa de CSB e o complexo transcricional. Por isso, a CSB é considerada a primeira proteína que responde a uma lesão no processo de TCR-NER (MORI, 2015).

O aumento de interação entre a CSB e a RNA pol ocorreria quando a transcrição fosse interrompida por alguma lesão na fita molde, o que se acredita que deslocaria CSB para trás (backtracking). Esse deslocamento desocuparia sítios de ligação e daria abertura para outras proteínas de reparo. De acordo que a RNA pol regride, a proteína de replicação $A$ (RPA, do inglês Replication Protein $A$ ) se liga aos sítios da fita simples impedindo a renaturação, além de sinalizar o recrutamento de XPA para o local da lesão. CSB também recruta CSA (Cockayne syndrome complementation group A). A CSA atua na ubiquinização de CSB, processo este que é muito importante para TCRNER, uma vez que CSB quimérica tem a capacidade de recuperar eventuais defeitos moleculares em CSB. A partir desse momento, os mecanismos de reparo de lesão são comuns entre TCR-NER e GGR-NER (CASTRO, 2016; MORI, 2015).

A sub via GGR-NER, como dito anteriormente, atua quando um dano a dupla fita do DNA distorce a estrutura espacial, comprometendo a dupla hélice. O reconhecimento se dá por dois complexos proteicos, o UV-DDB que é um heterodímero resultante da união de DDB1 e DDB2 e de outro heterodímero XPC-RAD23B/hHr23B-Centrina 2, que é o primeiro a reconhecer a lesão. A proteínas XPC é o componente do seu heterodímero que reconhece realmente a lesão, pois possui uma afinidade de ligação ao DNA e têm essa capacidade de ligação aumentada quanto mais distorcida for a lesão espacial da dupla hélice. O complexo UV-DDB reduz o tempo de reparo de CPD's e 6-4 PP's (fotoprodutos oriundos da interação entre os raios UV e a pele) devido a uma função estabilizadora que exerce em NER. Pacientes XP-E possuem diminuição acentuada no reparo de 6-4 PP's (CASTRO, 2016; FELTES, 2017; MORI, 2015; PUUMALAINEN, et al., 2015).

Depois do processo de identificação, os estágios subsequentes de NER seguem um caminho comum em ambas as sub vias com o recrutamento do TFIIH (Transcription Factor Human II), um complexo multiproteico com 10 subunidades, nas quais se encontram as proteínas XPB e XPD. Estas são helicases dependentes de ATP que desenrolam o DNA em polaridades opostas. A XPD desenrola no sentido 5'-3', 
enquanto a XPB na direção 3'-5'. A XPB pode ser mais eficiente na montagem de $\mathrm{TFIIH}$, do que no processo de helicase. A XPD possui um domínio estrutural em forma de arco bastante estreito pelo qual se desloca pela fita simples desenrolada. Como a dimensão do orifício formado pelo arco não é grande, a XPD pode ser considerada um fator de verificação de dano, pois lesões de grandes extensões não passarão devido ao obstáculo físico. Nesse contexto, até esse ponto tem-se a abertura da fita dupla e a verificação da lesão. Seguindo com o processo, o próximo passo é montar o complexo pré-incisional, com a ligação de XPA, RPA e XPG e desligamento do complexo XPC-hHR23B. Uma das funções de XPA é detectar alguma lesão que não foi percebida pela XPD, bem como se ligar no sentido oposto ao da XPB, na extremidade 5' da fita lesionada. A RPA se liga a fita não lesionada cobrindo cerca de três dezenas de nucleotídeos, e de ajudar no posicionamento correto das endonucleases, além deslocar a XPC, que deixa o complexo TFIIH. XPG e o complexo ERCC1-XPF são as endonucleases que receberam auxílio de RPA para se posicionarem e que farão a excisão do oligômero com a lesão e permitirão a continuidade do processo de reparo (CASTRO, 2016; MORI, 2015; SANTIAGO, 2015).

Para finalizar o processo, uma nova fita simples de DNA é sintetizado para ocupar o sítio danificado, havendo para isso a ação das polimerases pol $\delta$ e pol $\eta$ na síntese da nova fita e a ação da DNA ligase I ou II, que emenda a nova fita ao sítio (CASTRO, 2016; FELTES, 2017).

\section{A VIA DE REPARO POR SÍNTESE TRANSLESÃO}

A existência de uma lesão no DNA resulta em mudança na estrutura espacial da dupla fita, impossibilitando o reconhecimento das bases nitrogenadas pelas polimerases replicativas da família $A(\alpha, \beta, \varepsilon)$, que funcionam perfeitamente apenas em DNA íntegro, podendo levar a parada da forquilha de replicação e consequentemente a apoptose celular (LERNER, 2014; MORENO, 2017).

Polimerases da família Y, principalmente pol eta, são as mais qualificadas para efetuar o reparo do DNA danificado, pois apresentam sítios catalíticos palm and thumb 
menores, o que possibilita a inserção dos nucleotídeos mesmo com a presença da lesão na fita de DNA. Com esse processo, é evitada a parada da forquilha de replicação por um período longo, o que poderia desencadear um processo de apoptose celular (CASTRO, 2016).

No momento em que polimerases replicativas são impedidas de fazerem a replicação por algum impedimento físico existente na fita de DNA, o antígeno nuclear de proliferação celular (PCNA) terá sua lisina 164 monoubiquitinizada pelo complexo ubiquitina ligase E2/E3. Essa alteração promove o aumento da afinidade do PCNA com polimerases da família $\mathrm{Y}$, proporcionando uma convocação de polimerases da TLS, resultando na substituição das polimerases proliferativas, e interação da Pol eta com o local da lesão constituindo se o by-pass (CASTRO, 2016).

Feito o desvio por Pol eta ou por outra polimerase da família Y, outra polimerase da família B, principalmente Pol zeta, efetua a inserção de bases por mais alguns pares a frente. Despois do by-pass, Pol eta é desubiquitinizada pela proteína USP7. Com isso, polimerases da família $A$, principalmente Pol delta, continuam o processo de replicação do DNA (CASTRO, 2016; LERNER, 2014).

\section{OS TIPOS DE XERODERMA PIGMENTOSO}

O Xeroderma pigmentoso tipo A (XP-A) consiste em uma expressão fenotípica oriunda de alteração no gene XPA, o qual possui 6 éxons localizados no cromossomo 9q22.3 e extensão de $25 \mathrm{kpb}$. A proteína transcrita a partir do gene XPA apresenta 42 kDa e domínios que medeiam sua ligação ao DNA, os Dedos de Zinco - Zinc fingers (DANTAS, 2018; LEITE, 2008). Pacientes com deficiência nesse mecanismo celular tem prejudicada a capacidade de formar corretamente o complexo pré-incisional, que seria o arranjo correto da maquinaria celular nas extremidades da lesão do DNA (BENSENOUCl et al., 2016). No Japão e na Ásia, a maioria dos casos de XP são relacionados ao gene XPA, apresentando mutação no último nucleotídeo do éxon 3 (LEITE, 2008). 
O Xeroderma Pigmentoso tipo B é uma forma de manifestação da doença decorrente da não síntese da Proteína XPB/ERCC3. O gene XPB se localiza no cromossomo 2q21 e sua deficiência lesa o sistema nervoso, bem como faz parte da síndrome de Cockayne (DANTAS, 2018). A proteína XPB é uma helicase ATP (Adenosina Trifosfato) dependente que segue a fita de DNA no sentido 3'-5', recrutada após o reconhecimento inicial da lesão no momento em que o TCR (Reparo Acoplado à Transcrição) e o GGR (Reparo Genômico Global) convergem para uma via comum de NER (CASTRO, 2016).

O Xeroderma Pigmentoso tipo C (XP-C), por sua vez, ocorre quando anomalias genéticas afetam o gene XPC, o qual possui 16 éxons e $33 \mathrm{Kpb}$ e está localizado no lócus 3p25. A proteína transcrita a partir do gene XPC possui 940 aminoácidos e se liga a outras proteínas, a hHR23B e a centrina 2, formando um complexo proteico com domínio $C$ terminal de ligação ao DNA e ao fator de transcrição II humano, o qual reconhece lesões no DNA (LEITE, 2008). A mutação mais comum no gene XPC é uma deleção de $2 \mathrm{pb}$. De acordo com um estudo argelino ao analisar 17 pacientes com XP-C, todos apresentavam homozigose para a deleção de $2 \mathrm{pb}$. A deleção mais frequente resulta em um códon de terminação ineficiente, prejudicando a interação entre as proteínas XPC, hHR23B, Centrina 2 e TFIIH, que são essenciais no reconhecimento de danos no DNA, e início da via de reparo NER (BENSENOUCl et al., 2016).

O Xeroderma Pigmentoso tipo D está associada a defeitos no gene XPD, que se localiza no cromossomo 19.q13.2-13.3. A proteína transcrita a partir desse gene está relacionada com a excisão e reparo do DNA. Defeitos na expressão dessa proteína estão associados também a doenças como Tricodistrofia e Síndrome de Cockayne (DANTAS,2018). A proteína XPD é uma helicase de DNA que faz parte do TFIIH, responsável pela estabilização das proteínas no sítio da lesão. Além disso, XPD é dependente de ATP, e desenrola a dupla fita de DNA no sentido 5'-3', o inverso da proteína XPB (CASTRO, 2016; SOLTYS, 2010).

O Xeroderma Pigmentoso tipo E (XP-E), é ligado a mutações no cromossomo 11p12p11. O gene XPE é responsável pela síntese de proteína ligadora de DNA (DANTAS, 
2018). O produto codificado a partir do gene XPE é a proteína DDB2 (FELTES, 2017). A proteína XPE é formada por subunidades p127/DDB1 e p48/DDB2 e participa das vias de correção de lesões no DNA, reconhecendo lesões que não foram reconhecidas pelo complexo XPC-hHR23B como os dímeros de pirimidina ciclobutano (DPC's) (LERNER, 2014). A XPE é usada somente na sub via GGR-NER. Se tratando do TCR, tanto a proteína XPE quanto a XPC-hHR23B não são necessárias. O bloqueio físico do DNA para o prosseguimento da RNA polimerase II é o sinal de recrutamento dessa proteína (LEITE, 2008).

O Xeroderma Pigmentoso tipo F (XP-F), é oriundo de uma mutação no gene localizado no cromossomo 16p13.3-p13 (DANTAS, 2018). A proteína XPF se une a proteína ERCC1 e forma o heterodímero XPF-ERCC1. A proteína XPF é produto do gene XPF/ERCC4, com 103 kDa. A estabilização do complexo está associada a união das duas proteínas. O complexo XPF-ERCC1 possui um domínio localizado em XPF com propriedades catalíticas de nucleasse, participando da via NER do DNA. Ela também está presente em outras vias de reparo do DNA, tais como por DSB/QFD (Double Strand break ou Quebra na Dupla Fita) do DNA e por ligações cruzadas entre as fitas do DNA (LERNER, 2014). A incisão do oligonucleotídeo que possui a lesão só ocorre após a chegada do complexo XPF-ERCC1, que é o primeiro a fazer a incisão no sentido 3', deixando um radical hidroxil no qual será iniciado, por uma enzima DNA polimerase, a síntese de reparo (MORI, 2015).

O Xeroderma Pigmentoso tipo G (XP-G) está associado a anomalias no gene localizado no cromossomo 13q33 (DANTAS,2018). A proteína XPG é uma endonuclease que quebra o DNA lesado, sendo que sua ação começa cerca de 5 nucleotídeos antes do sítio da lesão no sentido 3'. A incisão na direção 5' pelo heterodímero XPF/ERCC1 também necessita da presença da proteína XPG na via de reparo NER. Pacientes que manifestam a doença XP-G possuem NER extremamente deficiente, e deficiências no gene que codifica XPG resulta no fenótipo XP/CS, quando o indivíduo apresenta concomitantemente Xeroderma pigmentoso e Síndrome de Cockayne. A XPG age como coativador de transcrição do PC4/CF4 (Positive Cofator 4 ou Cofator 4 positivo) que previne mutação e morte celular por danos oxidativos ao 
DNA. A PC4 atua retirando a XPG de regiões onde a RNA polimerase encontrou uma lesão, liberando o sítio para o processo de reparo. Além disso, a XPG estabiliza o TFIIH e permite a fosforilação de receptores nucleares, tendo um papel importante na expressão gênica (SOLTYS, 2010).

O Xeroderma Pigmentoso Variante (XP-V) é uma doença resultante da ausência da polimerase pol $\eta$, codificada a partir do gene POLH. A pol $\eta$ é composta por 11 éxons, 713 aminoácidos e tem como função central efetuar o by-pass do DNA (MORENO, 2017). Pacientes XP-V possuem a via de reparo do DNA por excisão de nucleotídeos normal, mas possui outros mecanismos de reparo defeituosos, como o mecanismo translesão que além de metabolizar foto produtos, degrada também espécies reativas de oxigênio (LIU; CHEN, 2006). A pol n consegue replicar DNA com lesões efetuando desvios, diminuindo a incidência de câncer pela diminuição da mutagênese. Em pacientes XP-V, locais lesados devido a exposição a luz UV têm a replicação do DNA interrompida e o desenrolar do processo fica mais propenso a erros pois a pol $\eta$ é a polimerase mais especializada em fazer o by-pass. Na ausência de pol $\eta$, outras polimerases da mesma família (como a pol ı) fazem o desvio, mas com baixa especificidade da inserção de bases correspondentes na fita complementar, ocasionando numerosas mutações que resultam em canceres de pele (LERNER, 2014; MORENO, 2017).

A polimerase pol $\eta$ pode realizar o by-pass nos dois principais fotoprodutos formados após a exposição à luz UV - os dímeros de pirimidina ciclobutano e 6,4 PP's -, além de agir também em bases oxidadas (MORENO, 2017). O conhecimento que se tem até 2017 sobre o XP-V é que seu desenvolvimento se dá a partir do contato com raios UVB e UVC. Entretanto, não se pode delimitar essa relação somente com esses comprimentos de onda, uma vez que são poucos os trabalhos que descrevem os efeitos mutagênicos de UVA em pacientes XP-V (MORENO, 2017). No Estado de Goiás, situado no Brasil, uma comunidade da cidade de Araras possui uma frequência de um caso de XP-V a cada 200 pessoas (MORENO, 2017). 


\section{AS MANIFESTAÇÕES CLÍNICAS DO XERODERMA PIGMENTOSO}

Indivíduos com XP-A seguem um curso clínico que resulta no aparecimento de sintomas neurológicos já na infância. Em pacientes com XP-A que atingiram a idade adulta, observa-se extensa perda neuronal e gliose da substância branca no sistema nervoso central (SNC). Acredita-se que fatores adquiridos, como o estresse oxidativo ou toxicidade aleatória dos aminoácidos, podem ter relação com manifestações neurológicas em pacientes no XP-A (UEDA et al., 2012).

Com relação ao XP-C, foi constatado por missionários da Good Samaritans International em parceria com médicos guatemalenses, que um povoado da Guatemala possui alta incidência de pacientes XP-C. Não havia apresentação de sintomas neurológicos, contudo as crianças não passavam dos dez anos de vida, tinham proliferação tumoral avançada, gangrena e infecção, com relato de dores intensas após exposição ao sol (CLEAVER, et al., 2011).

Devido a importante função da proteína XPD dentro da via de reparo NER, os pacientes XP-D apresentam grave deficiência da via NER, levando à degeneração neurológica de pacientes homozigotos em cerca de $20 \%$ a $30 \%$ dos casos (RIBEIRO et al., 2018).

Pacientes com XP-E, semelhante aos pacientes XP-C, normalmente não possuem doenças neurológicas, embora possam apresentar anormalidades no SNC por questões genéticas e ambientais em alguns casos (ORTEGA-RECALDE et al., 2013).

Da totalidade de pacientes com XP, $20 \%$ são XP-V e apresentam prognóstico mais favorável que XP clássicos (XP-A a XP-G), deficientes em NER. A fotossensibilidade de pacientes com XP-V se acentua no início da idade adulta, quando aparecem as primeiras lesões malignas. Ademais, indivíduos com XP-V não apresentam lesões neurológicas (LERNER, 2014).

Manifestações neurológicas são presentes em grupos de complementação XP-A, XPB, XP-D e XP-G (BENSENOUCl et al., 2016). 
Indivíduos XP apresentam maiores chances de desenvolverem neoplasias oculocutâneas em relação aos demais, sendo os principais tipos o carcinoma basocelular (CBC), carcinoma espinocelular (CEC) e melanoma (FELTES, 2014; HALKUD et al., 2014; OLIVEIRA et al., 2003).

Quanto às neoplasias oculares, pálpebras, conjuntiva e córnea são as regiões mais suscetíveis ao desenvolvimento de neoplasias (HALKUD et al., 2014).

$\mathrm{Na}$ literatura, há também relatos que regiões como cavidade oral, ponta da língua, medula óssea, testículos, estomago, pulmões e pâncreas em pacientes XP possuírem maiores chances de serem acometidas por uma neoplasia em comparação com as demais pessoas (FELTES, 2017; HALKUD et al., 2014).

\section{A RELAÇÃO ENTRE O XERODERMA PIGMENTOSO E 0 DESENVOLVIMENTO DE COMORBIDADES}

O surgimento de defeitos na via NER do DNA suscetibiliza o indivíduo acometido a desenvolver não somente XP clássicos, mas também outras doenças autossômicas e recessivas, como Síndrome de Cockayne, Tricotriodistrofia, Síndrome cérebro-óculofácio-esquelética, Sindrome UV-sensível, Síndrome XPF-ERCC1 e Síndrome $\mathrm{XP} /$ deSanctis-Cacchione, ambas apresentando como característica comum 0 aumento da sensibilidade aos raios UV (MOURA, 2015; SOLTYS, 2010).

A Síndrome de Cockayne é uma condição clínica associada, na maioria doa casos, a problemas neurológicos e de desenvolvimento físico, sendo classificada em cinco grupo de complementação de acordo com o lócus gênico afetado. Em dois destes grupos, as mutações ocorrem nos genes CSA (ERCC8) e CSB (ERCC6), resultando em um fenótipo com a via TCR do DNA prejudicada. Nos demais grupos, as mutações afetam os genes XPB (ERCC3), XPD (ERCC2) ou XPG (ERCC5) que, por sua vez, resultam em um fenótipo com a via NER deficiente. Em virtude disso, os grupos NERdeficientes correspondem aos indivíduos são suscetíveis a desenvolverem tanto Síndrome de Cockayne quanto XP, possuindo, maiores chances de desenvolver câncer de pele (CASTRO, 2016; SOLTYS, 2010). O quadro clínico do indivíduo com 
Síndrome de Cockayne pode incluir também perda auditiva neurossensorial, catarata, retinopatia pigmentar, fotossensibilidade cutânea e cárie dentária (CASTRO, 2016).

A Tricotiodistrofia trata-se de uma condição em que o indivíduo acometido não realiza corretamente a formação de pontes de sulfetos, interferindo assim na síntese de alguns aminoácidos que compõem o cabelo e as unhas, como a cisteína. Isso explica uma característica peculiar da doença: unhas frágeis e fios capilares quebradiços e ralos (CASTRO, 2016; SOLTYS, 2010). Outras manifestações que podem constar no quadro clínico de um indivíduo com Tricotiodistrofia incluem baixa estatura, microcefalia, déficit cognitivo, fácie característica - queixo recuado e orelhas grandes -, displasia das unhas, fotossensibilidade, ictioses, infertilidade e maior predisposição a doenças infecciosas (CASTRO, 2016). Tratando-se da genética da doença, quatro genes associados ao desenvolvimento da Tricotiodistrofia já foram identificados: XPD, XPB, TTDA e TTDN1. Enquanto que o último não possui suas funções esclarecidas, sabe-se que os três primeiros codificam proteínas que integram o $\mathrm{TFIIH}$, estrutura associada a via NER do DNA (SOLTYS, 2010).

A Síndrome XP/deSanctis-Cacchione consiste em um quadro de XP associado à coexistência de hipogonadismo, nanismo e doença neurológica severa no indivíduo acometido. Os estudiosos que dão nome à síndrome foram os primeiros a estabelecerem uma relação entre o XP e anormalidade neurológicas (LERNER, 2014; SOLTYS, 2010).

Além das doenças mencionadas, constata-se também que indivíduos XP apresentam maiores chances de desenvolverem neoplasias oculocutâneas em relação aos demais, risco esse avaliado em mil vezes maior. Nos casos de XP do tipo C e E, evidencia-se maior incidência de câncer de pele (FELTES, 2014; HALKUD et al., 2014; OLIVEIRA et al., 2003).

Os principais tipos de neoplasias oculocutâneas que afetam indivíduos XP são o carcinoma basocelular (CBC), carcinoma espinocelular (CEC) e melanoma, sendo os dois primeiros os mais frequentes. O CBC é caracterizado por um crescimento mais 
lento e menores chances de metastatizar, enquanto que o CEC possui características opostas (HALKUD et al., 2014; OLIVEIRA et al., 2003).

Quanto às neoplasias oculares, têm-se que a maior exposição aos raios UV do sol suscetibilizam principalmente pálpebras, conjuntiva e córnea ao desenvolvimento dessas neoplasias.

$\mathrm{Na}$ literatura, há relatos que regiões como cavidade oral, ponta da língua, medula óssea, testículos, estomago, pulmões e pâncreas em pacientes XP possuírem maiores chances de serem acometidas por uma neoplasia em comparação com as demais pessoas (FELTES, 2017; HALKUD, 2014). Com maiores chances de desenvolver neoplasias, principalmente envolvendo a pele, os pacientes XP minimizam sua expectativa de vida (MOURA, 2015).

\section{TRATAMENTO}

O XP não tem cura por se tratar de uma doença genética e as medidas adotadas para o tratamento são paliativas, buscando aumentar a expectativa de vida do paciente. Basicamente, o tratamento gira em torno de remoção de eventuais tumores que surgirem, recomendando-se um acompanhamento com dermatologista. É necessário que o paciente XP mude seus hábitos de vida, usando roupas longas e diminuindo as áreas expostas à luz. Além disso, o exercício de atividades no período noturno, em vez do período diurno e vespertino, minimiza o contado do paciente XP com a maior fonte de luz UV que se possui na Terra, o sol (LERNER, 2014).

É relatado que o uso de isotretinoína (ácido cis-retinóico) reduz o aparecimento e proliferação de neoplasias de pele em pacientes que possuem alta incidência de câncer. Uma outra opção é o uso de enzimas de reparo encapsuladas em lipossomos, como a $T_{4}$ endonucleose $V$ e a CPD-fotoliase, que reparam lesões CPD's. A enzima $\mathrm{T}_{4}$ endonucleose $\mathrm{V}$ corta a fita de DNA lesionada e metaboliza, gerando produtos acessíveis a maquinaria celular. Enquanto a CPD fotoliase, quebra ligações no anel ciclobutano formado entre as pirimidinas. Para o reparo de 6-4 PP's existem as 6,4 PP's fotoliases que precisam ser ativadas pelo uso de radiação UVA, o que gera um 
certo receio no uso desse recurso pois UVA pode causar outras lesões que podem ser problemáticas aos seres humanos (LEITE, 2008).

Outra ferramenta de tratamento é o uso de vetores adenovirais. Em síntese, o domínio terminal de formato globoso do adenovírus interage com o receptor CAR (CoxsackieAdenovirus Receptor). Após interações entre o vírus e a superfície celular, ocorre o sinal para endocitose e o adenovírus é internalizado, liberado pelo endossomo e movido para o núcleo celular por microtubulinas. Se faz necessário esclarecer que na construção de vetores adenovirais, regiões são removidas e para que sejam inseridas outras de interesse. Foram obtidos por meio da engenharia genética adenovírus recombinantes para os genes XPA, XPC, XPD e XPV, que são eficientes para a transdução e complementação dos processos celulares em humanos (LEITE, 2008). Por meio de uma técnica baseada em retrovírus, a transcomplementação da proteína XPC foi relatada, transduzindo a XPC em células tronco humanas, restabelecendo a capacidade total de NER. Apesar do sucesso in vitro, na prática o retrovírus pode causar efeitos colaterais não controláveis por quem aplica a técnica - como por exemplo prejuízos em vias hematopoiéticas (DUPUY, et al., 2013).

A criocirurgia ou crioterapia também é uma ferramenta alternativa para o tratamento de pacientes XP, técnica esta que consiste no congelamento da área lesionada e a indicação para esse tipo de procedimento leva em conta o aspecto macroscópico da lesão, dimensões, local, composição histológica e idade do paciente. A criocirurgia usa principalmente nitrogênio líquido e consiste em um congelamento muito rápido e severo, com posterior descongelamento lento, provocando a morte celular da região afetada (ANTUNES; ANTUNES; SILVA, 2007).

O uso de terapia fotodinâmica (TFD) é uma ferramenta que possibilita o tratamento dos canceres oriundos do XP, sem métodos invasivos ou uso de quimioterápicos tóxicos a tecidos saudáveis. É relatado que estudos clínicos usando ácido metil-סaminolevulínico e luz vermelha se mostraram uma boa alternativa para o tratamento de câncer basocelular superficial em pacientes XP (ZAMARRÓN et al., 2017). 


\section{CONCLUSÃO}

O XP é uma doença genética que não tem cura, decorrente de defeitos advindos da via NER e na via TLS de reparo do DNA, podendo assumir 8 tipos diferentes de manifestações.

O indivíduo com XP possui uma pele fotossensível e quando exposto a radiação UV pode desenvolver diversas complicações dermatológicas, possuindo chance exponencialmente maior de desenvolver cânceres basocelulares, espinocelulares e melanomas quando comparado a um indivíduo normal para o XP, além de prejuízos neurológicos e oftalmológicos.

Manifestações do XP estão diretamente ligadas ao defeito genético que precede sua manifestação fenotípica, apresentando pontos ineficientes na cadeia de reparo do DNA que mudam de acordo com o tipo de XP.

NER é sem dúvida a principal via de reparo do DNA quando se trata de XP, pois 7 tipos de XP são decorrentes desse mecanismo de correção de lesões do DNA. NER é subdividida em duas sub vias: TCR-NER e GGR-NER, sendo a primeira atuante nas situações de bloqueio da elongação do RNA e a segunda quando há dano espacial à fita dupla de DNA.

No XP-V o by-pass da fita coma lesão do DNA não é feito pela polimerase pol eta e sim por outra polimerase da familiaY o que acarreta numa taxa muito maior de erros na via de reparo TLS. Pol eta consegue inserir nucleotídeos na fita de DNA mesmo com a presença da lesão, e é a polimerase da família Y com a taxa de erros menor.

Defeitos nas vias de reparo do DNA podem causar outras doenças além do XP como: Síndrome de Cockayne e Tricotriodistrofia, podendo ter inclusive manifestações concomitantes como a Síndrome XP/deSanctis-Cacchione.

O tratamento para o XP é paliativo. Consiste em protetores UV específicos, fármacos, enzimas de reparo, vetores adenovirais, criocirurgia, TFD, remoção cirúrgica de tumores e acompanhamento psicológico. 


\section{REFERÊNCIAS}

ANTUNES, A. A.; ANTUNES, A. P.; SILVA, P. V. A criocirurgia como tratamento alternativo do xeroderma pigmentoso. Revista Odonto Ciência, v. 22, n. 57, p. 228232, set. 2007.

BENSENOUCI, S.; LOUHIBI, L.; VERNEUIL, H.; MAHMOUDI, K.; SAIDI-MEHTAR, N. S. Diagnosis of Xeroderma Pigmentosum Groups $A$ and $C$ by Detection of Two Prevalent Mutations in West Algerian Population: A Rapid Genotyping Tool for the Frequent XPC Mutation. BioMed Research International, v. 2016, n. 2180946 jun. 2016.

CASTRO, L. P. Caracterização genotípica de pacientes brasileiros com deficiência em processos de reparo de DNA. Tese (Doutorado em Biotecnologia) - Universidade de São Paulo. São Paulo, p. 36. 2016.

GOLDMAN, L.; AUSIELLO, D. Cecil Medicina. 23. ed. Rio de Janeiro: Elsevier, 2011.

CHAIBUB, S. C. W. Alta incidência de Xeroderma Pigmentosum em comunidade no interior de Goiás. Surg Cosmet Dermatol, Goiânia, v. 3, n. 1, p. 81-83, jan/mar. 2011.

CLEAVER, J. E.; FEENEY, L.; TANG, J. Y.; TUTTLE, P. Xeroderma Pigmentosum Group $C$ in an Isolated Region of Guatemala. Journal of investigative dermatology, v.127, n. 2, p. 493-496., fev. 2007.

DANTAS, E. B. XERODERMA PIGMENTOSO: RELATO DE CASO. Tese (Trabalho de Conclusão de Curso de Medicina) - Universidade Federal de Sergipe. Lagarto, p. 38, 2018.

DUPUY, A.; VALTON, J.; LEDUC, S.; ARMIER, J.; GALETTO, R.; GOUBLE, A.; LEBUHOTEL, C.; STARY, A.; PAQUES, F.; DUChATEAU, P.; SARASIN, A.; DABOUSSI, F. Targeted Gene Therapy of Xeroderma Pigmentosum Cells Using Meganuclease and TALEN. PLoS One, v. 8, n. 11., páginas, nov. 2013. 
FELTES, B. C. Estudo conformacional do complexo proteico DDB2-DDB1 e suas diferentes variantes mutantes na doença Xeroderma Pigmentosum. Tese (Doutorado em Biologia celular e molecular) - Universidade Federal do Rio Grande do Sul. Porto Alegre, p. 100. 2017.

HALKUD, R.; SHENOY, A. M.; NAIK, S. M.; CHAVAN, P.; SIDAPPA, K. T.; BISWAS, S. Xeroderma pigmentosum: clinicopathological review of the multiple oculocutaneous malignancies and complications. Indian Journal of Surgical Oncology, v. 5, n. 2, p. 120-124, abr. 2014.

LEITE, R. A. Uso de vetores adenovirais no diagnóstico de portadores de xeroderma pigmentosum e em estudos de reparo de DNA. Tese (Doutorado em microbiologia) Universidade de São Paulo. São Paulo, p. 41, 2008.

LERNER, L. K. Papel das proteínas XPD e DNA polimerase eta nas respostas de células humanas a danos no genoma. Tese (Doutorado em Ciências) - Universidade de São Paulo. São Paulo, p. 201. 2014.

LIU, G.; CHEN, X. DNA Polymerase $\eta$, the Product of the Xeroderma Pigmentosum Variant Gene and a Target of p53, Modulates the DNA Damage Checkpoint and p53 Activation. American Society of Microbiology, v. 26, n. 4, p. 1398-1413, fev. 2006.

MORENO, N. C. Efeitos da luz UVA em células de pacientes com Xeroderma Pigmentosum Variante. Tese (Doutorado em Genética) - Universidade de São Paulo. São Paulo, p. 39. 2017.

MORI, M. P., Novo papel da proteína XPC na regulação dos complexos da cadeia de transporte de elétrons e desequilíbrio redox. Tese (Doutorado em Bioquímica) Universidade de São Paulo. São Paulo, p. 174. 2015.

MOURA, L. M. S. Busca de variantes em sequência de DNA proveniente de pacientes com deficiência em processos de reparo do genoma. Tese (Mestrado em Bioinformática) - Universidade de São Paulo. São Paulo, p. 80. 2015. 
OLIVEIRA, C. R. D; ELIAS, L.; BARROS, A. C. M; CONCEIÇÃO, D. B. Anestesia em Paciente com Xeroderma Pigmentoso. Relato de Caso. Revista Brasileira de Anestesiologia, Florianópolis, v. 53, n. 1, p. 46-51, jan/fev. 2003.

ORTEGA-RECALDE, O. O.; VERGARA, J. I.; FONSECA, D. J.; RIOS, X.; MOSQUERA, H.; BERMUDEZ, O. M.; MEDINA, C. L.; VARGAS, C. I.; PALLARES, A. E.; RESTREPO, C. M.; LAISSUE. P. Whole-Exome Sequencing Enables Rapid Determination of Xeroderma Pigmentosum Molecular Etiology. Plos One, v. 8, n. 6, jun. 2013.

PRIBERAM

DICIONÁRIO.

Disponível em:<https://dicionario.priberam.org/quadro\%20clinico>. Acesso em: 24 mar. 2020.

PUUMALAINEN, M. R.; RUTHERMANN, P.; MIN, J. H.; NAEGELI, H. Xeroderma pigmentosum group $\mathrm{C}$ sensor: unprecedented recognition strategy and tight spatiotemporal regulation. Cellular and Molecular Life Sciences, v. 73, 547-566, out. 2016.

RIBEIRO, M. G.; ZUNTA, G. L.; SANTOS, J. S.; MORAES, A. M.; LIMA, C. S. P.; ORTEGA, M. M. Clinical features related to xeroderma pigmentosum in a Brazilian patient diagnosed at advanced age. Dove Medical Press, v. 11, p. 89-92, ago. 2018.

SANTIAGO, S. P. Estudo de polimorfismos de genes de reparo do DNA em lesão de fita simples e sua associação com aspectos clínicos e laboratoriais de portadores de síndrome mielodisplásica. Tese (Mestrado em ciências médicas) - Universidade Federal do Ceará. Fortaleza, p. 111. 2015.

SCOTTINI, A. Dicionário escolar da língua portuguesa. Blumenau: Todolivro Editora, 2017.

SOLTYS, D. T. Análise da natureza genotípica de pacientes Xeroderma pigmentosum Brasileiro. Tese (Doutorado em Microbiologia) - Universidade de São Paulo. São Paulo, p. 43. 2010. 
UEDA, T.; KANDA, F.; AOYAMA, N.; FUJII, M.; NISHIGORI, C.; TODA, T. Neuroimaging features of xeroderma pigmentosum group A. Brain and Behavior, v. 2, n. 1, p. 1-5, jan. 2012.

VIANA, F. O.; CAVALEIRO, L. H. S; CARNEIRO, C. M. M. O.; BITTENCOURT, M. J. S.; BARROS, R. S.; FONSECA, D. M. Você conhece esta síndrome? Síndrome de DeSanctis-Cacchione: relato de caso com esquizencefalia. Anais Brasileiros de Dermatologia, v. 86, n. 5, p.1029-38, 2011.

ZAMARRÓN, A.; GARCÍA, M.; RÍO, M.; LARCHER, F.; JUARRANZ, A. Effects of photodynamic therapy on dermal fibroblasts from xeroderma pigmentosum and GorlinGoltz syndrome patients. Oncotarget, v. 8, n. 44, p. 77385-77399, set. 2017.

Enviado: Março, 2020.

Aprovado: Março, 2020. 